\title{
Role of Marketing Strategy in the Relationship between Market Orientation and Hospital Performance (A Study of the Regional Public Hospital (RSUD) in Southeast Sulawesi Province)
}

\author{
La Ode Kamalia ${ }^{1}$, Alida Palilati ${ }^{2}$, Endro Sukotjo ${ }^{3}$, La Hatani ${ }^{4}$ \\ ${ }^{1}$ Doctoral Program of Management Science, Halu Oleo University, Kendari, Indonesia \\ 2, 3, ${ }^{4}$ Department of Management, Faculty of Business and Economic, Halu Oleo University, Kendari, Indonesia
}

\begin{abstract}
The purpose of this paper is to explore the impact of market orientation on the marketing strategy and hospital performance and to explain the role of marketing strategy as mediator for the relation between market orientation and hospital performance. Design of this research was an explanatory, whereas data collection used a survey method. Unit analysis of this research was executive manager in Regional Public hospital in Southeast Sulawesi province of both structural and functional managers. The numbers of sample were determined by a Slovin formula and were selected with a proportional stratified random sampling technique. Therefore the numbers of samples of this research were 291 peoples. Data analysis used a Partial Least Square (PLS). The results of this research shown that the implementation of the best market orientation have a significantly contributed to increase the marketing strategy and hospitals performance. The marketing strategy had positive and significant effect on the performance of hospitals. Finally, marketing strategies becomes a partial mediation relationship between market orientations on hospitals performance. The practical implications of this research are to provide knowledge understanding of the conceptual integration of structural relations and the importance of aspects: market orientation and marketing strategy in the management of hospitals through a referral system orientation, product (services) strategy and market share. Originality of this research proves the conceptual model which integrated into the effect of the market orientation which had positive and significant effect on the marketing strategy and hospitals performance, marketing strategy on hospitals performance, as well as through the influence of the mediation role of the marketing strategy.
\end{abstract}

Keywords: Market Orientation, Marketing Strategy, Hospital Performance

\section{Introduction}

Marketing hospitals around the world are facing increasing competition is no exception in India (Sreenivas, et al., 2013), and also in Singapore, Malaysia and Indonesia. This increase along with the progress of science and technology, the development of human rights, changing tastes, lifestyles and shifting patterns of disease in the community from infectious diseases to degenerative disease and then the emergence of new infectious diseases as well as long and difficult. In Indonesia, which occurred on the marketing of the hospital, which is not only the competition among hospitals, but also the public demands of malpractice is rampant in the media. This condition can be seen from the use of international standard hospitals labels, promotional success of conjoined twins' separation surgery, plastic surgery, IVF, and so on up to the greater incentives for specialists. While malpractice ranging from services that do not fit the standard operating procedures, patient neglect, abortion, wrong medication, and so forth until the disappearance and death of the baby.

The above facts, demands the ability of hospital management professional in the face of competition to be able to supply all the demand, desires and needs and community demands for a satisfactory quality of service and malpractice. If the hospital does not have the ability to compete and overcome the malpractice will be abandoned by the customers. That is why; hospitals in many countries follow the lead of the world's leading countries in the field of hospital accreditation, (Department of Health, 2004). To address the importance of standardization and accreditation in improving the quality of hospital services and patient safety, the hospital accreditation in Indonesia inserted into the Act R.I. No. 44 Year 2009 regarding Hospital in Article 40, as an obligation.

Various studies showed that the low performance of the hospital industry is the effect of the weak market orientation. For example, research conducted by Narver and Stanley F. Slater, (1990); Raju P.S. et al, (2000); Esteban et al, (2001), Lonial S.C. \& Raju P.S., (2001); Lings Ian, (2002); Gopalakrishna P. \& Ram Subramanian, (2004); Schalk Adrianus Philip, (2008); Beracs \& Gabor naggy, (2010); Asikhia Olalekan, (2011); Susana Fonseca \& Alberto Baptista, (2012); Idar Riduwan et al, (2012); Sin Leo Y.M. et al, (2013; 2004); and Acikdilli G., (2013). Similarly, research on the effects of the weak marketing strategies on the performance conducted by Akinyele Samuel Taiwo, (2011; 2010); Ahmad, et al, (2013); Dolata Badi, et al, (2013); and Mwangi \& Kepha Ombui, (2013), as well as the effects of the lack of orientation and marketing strategies simultaneously on the performance, as was done by Kamalia \& John Suprihanto, (1998); Heiens \& Larry P. Pleshko, (2011); and Kamalia (2012 and 2013).

In the industrial sector health care (hospitals), implementation of marketing has increased rapidly and extensively since the 1980s. In January 1999, the British National Health Service (NHS) reported the onset of the 


\section{International Journal of Science and Research (IJSR) \\ ISSN (Online): 2319-7064}

Index Copernicus Value (2013): 6.14 | Impact Factor (2015): 6.391

crisis marketing during the month, in which the patient's accident and emergency at the hospital waiting for a long time, few cases are brought to the hospital waiting on a trolley because of lack of beds, and financing (Sheaff Rod, 2002). The fact happens because the indication of weaknesses in the application of marketing in the health care sector are not well understood (Mutongoreni \& Nelson Jogero (2014). Consistent with the statement Kotler et al, (2008), that the marketing staff must develop a marketing plan that is sufficient brilliant, but it is not applied properly to achieve success. Similarly, Bennett (1989) and Burcley Patrict (2009) stated that marketing in the healthcare industry in the hospital has the characteristics and uniqueness than marketing in other service industries. Characteristics and uniqueness this is similar to the one disclosed, by Kotler et al (2008: 2), that "health care is one industry that is vast and complex found in the modern economy." Alluding to this, where every family in need services must involve careful consideration of a considerable number of institutions and professionals.

The low performance of the regional hospital in Indonesia, the necessary transformation of professional management by managers expert in the field of hospital management without having to consider unilateral desire, but for the sake of public interests and the progress of the hospital, in order to fulfil its social responsibility. In connection with that, the policy makers are supposed to be kept in mind what have been revealed by Scott Becker, et.al. (2012), stated that: "there are eight issues that are very challenging and interesting for the movement of hospitals and health care systems in the Year 2013, namely: (1) physician alignment, (2) the sustainability of independent hospital, (3) accountable care organizes , (4) leadership physician burn out, (5) chief executive officers concerns, (6) orthopaedics, (7) population health, and (8) healthcare information technology.

Based on the Health Profile of Southeast Sulawesi province from 2008 to the Year 2012 showed that the hospital BOR average stands at 34-50\%. In 2013 the number of beds 1,464 beds, the total number of patient visits and hospitalizations 52955221135 days the number of days of care, the number of recorded deaths and deaths in 1,687 patients on 48 hour recorded 616 patients. From these data, showed an average of hospital performance indicators, namely: BOR amounted to $41.38 \%$, LOS of 4.2 days, BTO 36, 2 times, TOI at 5.92 days, GDR amounted to $3.19 \%$ and NDR of $1.16 \%$. (Southeast Sulawesi Provincial Health Office, 2013). Achievement of hospital performance indicators above indicates that the performance of the region in general hospitals, BOR, ALOS, and TOI are under national indicators. While the GDR and NDR generally meet national indicators. When examined data every hospital, indicating that all the regional hospital average performance is still relatively low. As a result of a decrease in the BOR for example, hospitals Bahteramas Southeast Sulawesi province in 2013 decreased revenue obtained, namely "do not cover costs" according to Chairman of the Supervisory Board of Internal Hospital Bahteramas Southeast Sulawesi province, when confirmed in his office in January 2014. In the case ideal indicators set by the government, the cost recovery of $>$ $40 \%$ (Department of Health, 2008).
Ironically, the death rate is still very high compared with the target indicators ideally. For example hospitals of Bau-bau in 2007-2012 showed an average of $39 \%-50 \%$ BOR, GDR $55.70 \%-60.95 \%$, and the NDR stands at $20.67 \%-22.43 \%$ (City Hospital Bau-bau, 2012). In 2013 hospitals Muna GDR 31.4\%, Hospital of Bau-bau 57.2\% and 7.0\% Wakatobi district hospitals; and the Hospital of Bau-bau 19.7\% (Southeast Sulawesi Provincial Health Office, 2013). These data illustrate that the performance of hospitals in Southeast Sulawesi is still relatively low. Thus the key issue of this study are: (1) does the application of market orientation affect the marketing strategy and the performance of hospitals? (2) Is the implementation of marketing strategies on the performance of hospitals? and (3) is the marketing strategy acts as a mediating influence between market orientation with the performance of hospitals? Furthermore, the purpose of this study was to test and explain the effect of the application of market orientation and marketing strategies to increase the performance of hospitals. Specifically the purpose of this study was to examine and explain the role of marketing strategies as a mediating influence between market orientations with the performance of hospitals. The contribution of this study is expected to guide the development of policies for owners of hospitals to implement hospital marketing management system to improve hospital performance better. In addition expected to be learning information on the education of health management and hospital management, and becomes information for further research.

\section{Research Methods}

The design of this research was aimed to give explanation towards development strategy of the hospital industry in Southeast Sulawesi province by using market orientation and hospital performance based. The approach used in this research was positivistic paradigm by using explanatory research, which data collection was taken from survey method. Explanatory research is intended to explain the causal relationship between variables through hypothesis testing, or testing is to obtain the right to draw conclusions that are causality between variables and then choose an alternative action (Cooper \& Sehindler, 2003). The underlying reasons for the use of this explanatory research for the purpose of research is to examine and explain the effect of the application of market orientation and marketing strategy either directly or indirectly (mediation) that includes variable marketing strategy with the performance of district general hospitals.

This research will be implemented in all government hospitals of the district/city in Southeast Sulawesi, namely: Hospital Abunawas Kendari, hospitals Konawe, hospitals Kolaka, hospitals Konsel, hospitals Oheo North Konawe, hospitals Bombana, hospitals district Muna, Hospital of BauBau, Buton District Hospital, Hospital Wakatobi, Buton District Hospital North, and North Kolaka District Hospital (Southeast Sulawesi Provincial Health Office, 2013).

The population in this study are all executive officers of the regional hospital officials both structural and functional 


\section{International Journal of Science and Research (IJSR) \\ ISSN (Online): 2319-7064}

Index Copernicus Value (2013): 6.14 | Impact Factor (2015): 6.391

officials numbering 336 people spread across 12 hospitals district / municipal in Southeast Sulawesi Province. An official's structural and functional element of the leadership of the hospital is a hospital that became a key element and involved in improving hospital performance. Thus the unit of analysis in this study is the hospital management (Director, Head of Section, Head of Division, Head of Section, Head of Section, Head of Service Unit Functional consists of: ER, Radiology, Pharmacy Installation, Laboratory, Installation Nutrition, Inpatient, Outpatient, General Polyclinic, Polyclinic Specialist, Dental Clinic and head of the room). Thus the size of the sample can be quantified using the formula Slovin Uma Sekaran (2003), as follows:

$\mathrm{n}=\frac{\mathrm{N}}{1+\mathrm{N}(\mathrm{e})^{2}}=\frac{336}{1+336(0,04)^{2}}=218.52$ or 219 people

Where: $\mathrm{n}=$ number of samples; $\mathrm{N}=$ Number of population $\mathrm{e}$ $=$ percentage of looseness (precision) due to sampling error that can be tolerated or desirable $(0.05 \%)$.

The samples of this study using techniques of probability sampling, the sampling technique used was stratified proportional random sampling, the first classifying the population into sub-populations based on the work area ie 12 hospitals district/city in Southeast Sulawesi, then stratified by type functional and structural. Of the total population of 336 officials of the structural and functional hospital, then obtained a sample size of 219 people. Thus the number of sampling defined in this study as many as 219 people. Data measurement of all variables in this research used Likert scale. A five-point Likert scale was employed with a score of 1, indicating "strongly disagree", and 5, representing "strongly agree", to extract the different attitudes of respondents Malhotra (2010); Cooper \& Sehindler (2003).

Techniques of analysis in this study use quantitative analysis approach. For Test hypotheses and to generate an appropriate model the analysis used in this study is with a process aided calculation application, in the form of software. The method for data analysis in this research is Structural Equation Model on the basis of variant that is called Partial Least Square (PLS). PLS application allows for multi co linearity, that is strong correlation among exogenous variables. The reasons for choosing PLS in this research are: (1) the model formed at conceptual framework has hierarchical causal relation, that is competence and commitment, which have an impact on performance and then have an impact on satisfaction with reward as a moderating variable. Due to the hierarchy, a structural model would be quite useful here; (2) this study uses latent variable which is measured through indicators and PLS would be appropriate here for confirming the unidimensionality of the various indicators for latent variable; (3) PLS is a powerful method of analysis which does not require much assumption and allows for analyzing a set of latent variables simultaneously; (4) the PLS method is easier to run since it does not require index modification. In PLS analysis, measure of fit (goodness of fit) can be done in model measurement, structure and overall model even in combination between model measurement and structural model particularly in reflective indicators.
In this research, all latent variables were measured by reflective indicators. Thus, evaluation of the model measurement can be done: (1) latent construct is concerned has convergent validity, if the estimation scores of loading $\geq$ .70 and score of t-statistic and p-value significant at $\alpha=.05$. Correlation score between reflective indicator and the latent variable; (2) Test of discriminant validity by looking at the AVE (Average Variance Extracted) score. Recommended AVE value $\geq 0.50$ can be considered if the latent variables have good discriminant validity; (3) Latent variable has good composite reliability if the value $\geq 0.70$ Solimun, (2012) \& Hair et al., (2010). Hypothesis test by using resampling bootstrap method was developed by Geisser and Stone as quoted from Solimun (2012). Statistical test used was CR alike with t-test. Implementation of resampling model enable data distributed freely, thus need not normal distribution assumption as well as not need big sample. Sample of bootstrap suggested about 500, due to with a sample of 500 can produce stable parameter estimation. Finally hypothesis test can be carried out by comparing p-value $\leq \alpha=0.05$ ).

\section{Analysis and Results}

A sample of respondents of this study is the executive officer of the regional hospital officials both structural and functional officials numbering 219 people distributed in 12 hospitals district / municipal in Southeast Sulawesi Province. Of the 219 questionnaires were given to respondents only 191 were filled completely or approximately $87.15 \%$, which can be used. The remaining 12 respondents (5.48\%) do not return, and 16 respondents (7.31\%) are not filled completely. Thus methodologically of 191 respondents or $87.15 \%$ feasible for examination and discussion of results. Profile of respondents is aimed to describe characteristics of the respondent's sampled based on sex, age, work duration, and education level.

Table 1 shows that majority of respondents are men 56.54\%. Then based on age characteristics, majority respondents are between $31-50$ years old (72.25\%), theoretically generated as productive age. Profile of respondents based on working experience majority between 10-19 years (74.87\%). These facts reflected that respondents have been working for over than ten years, which were expected to be more professional and experts in managing hospital. Profile respondents based on education level were majority bachelor degree (64.40\%). Therefore, by having high education of the respondents were expected to have ability in completing tasks, adopting new technologies and information in the health care process so as to improve hospital performance. Result of respondents profile is presented in Table 1.

Table 1: Profile of Research Respondents \begin{tabular}{|l|l|} 
Respondents profile & Percent \\
\hline
\end{tabular} 


\begin{tabular}{|l|l|c|}
\hline 1. Sex & Man & 56.54 \\
& Woman & 43.46 \\
\hline 2. Age (years) & $21-30$ & 16.23 \\
& $31-40$ & 40.84 \\
& $41-50$ & 31.41 \\
& $51-57$ & 11.52 \\
\hline 3.Working duration (years) & $2-9$ & 7.85 \\
& $10-19$ & 74.87 \\
& $20-25$ & 12.04 \\
& $26-31$ & 5.24 \\
\hline 4. Education Level & High School & 3.66 \\
& Diploma & 19.90 \\
& Bachelor & 64.40 \\
& Magister & 12.04 \\
\hline
\end{tabular}

Notes: $\mathrm{n}=191$

Result of respondent's assessment towards indicator of variable assessment which was reflected by mean score was expected to know the actual condition of every indicator based on respondent's perspective. Then, score of loading factor was expected to know the strongest variable assessment towards every indicator in reflecting the variables. Table 2 Shows respondents assessment towards variable of market orientation with mean $=4.06$ or majority of respondents stated good. Next, variable orientation accreditation of has the biggest mean compared to customer orientation, competitor orientation, inter-functional coordination orientation, growth orientation, environmental health orientation, and referral system orientation. This result was not supported by score of loading factor that indicator of referral system orientation is concerned the most dominant in reflecting variable of market orientation $=0.831$. It can be concluded that the orientation reference system is the ability of hospitals into a referral centre, providing resources hospitals are required, establish cooperation with the leadership of the health facility, facilitate the access of patients in need of referral services, referring patients to health care facilities better, foster care facilities are needy, and restore the patient after getting follow-up care with the information deemed most important or dominant in reflecting the variable orientation of the market.

Marketing strategy, which is a set of variables that can be controlled by the hospital to use and affect the response of the patient and his family. The ability to respond from patient and his family must be integrated especially for product (services) strategy, pricing, place (location), promotion, physical evidence, process or service delivery, people or personnel, and patient safety strategy. Response of respondents majority said good in the scale in the implementation of marketing strategy with mean score = 3.89. Result of model evaluation in measuring indicator of product (services) strategy $=0.877$ is considered important to reflect marketing strategy, but, has not been implemented well. This fact showed by response of respondents from the mean score, indicator of patient safety strategy is considered the most priority in the implementation of marketing strategy. Measurement of variable of hospital performance based on response of respondents is categorized well with mean score = 3.87. Next, variable Bed Occupancy Rate (BOR) of has the biggest mean compared to cost recovery, market share, employee satisfaction, patients and their family's satisfaction.
This result was not supported by score of loading factor that indicator of market share is concerned the most dominant in reflecting variable of hospital performance $=0.835$. It can be concluded that indicators of market share, as reflected by the ratio of the share of each hospital to the overall number of patients in its area of responsibility as a whole has reached the target outpatient $15 \%$ of inpatient $2 \%$ of the total population and utilization of all patients from poor families 100 deemed most important or dominant in reflecting the performance Hospital.

Score of AVE in Table 2 shows all constructs have good discriminant validity. Therefore, instrument which was used in this research we fit to be used for measurement because it fit the criteria of discriminant validity. Next, score of alpha $\geq$ 0.70 means that all variables examined have good reliability.

Table 2: Mean, Factor Loading, AVE and Composite Reliability

\begin{tabular}{|c|c|c|c|c|c|c|}
\hline \multirow{2}{*}{ Constructs/Indicators } & \multirow{2}{*}{ Mean } & \multicolumn{3}{|c|}{ Factor loading } & \multirow{2}{*}{ AVE } & \multirow{2}{*}{$\begin{array}{l}\text { Composite } \\
\text { Reliability }\end{array}$} \\
\hline & & Estimate & SE & T-Statistic & & \\
\hline Market Orientation (MI0): & 4.061 & & & & 0.571 & 0.902 \\
\hline M01. Customer orientation & 4.199 & 0.708 & 0.049 & 14.528 & & \\
\hline M02. Competitor orientation & 3.846 & 0.780 & 0.039 & 19.752 & & \\
\hline M03. Interfunctional coordination orientation & 3.853 & 0.652 & 0.064 & 10.232 & & \\
\hline M04. Growth orientation & 3.960 & 0.747 & 0.034 & 21.777 & & \\
\hline M05. Environmental health orientation & 4.109 & 0.807 & 0.024 & 33.488 & & \\
\hline M06. Orientation referral system & 4.120 & 0.831 & 0.022 & 37.148 & & \\
\hline M07. Orientation accreditation & 4.305 & 0.750 & 0.033 & 22.483 & & \\
\hline Marketing Strategy (MS): & 3.892 & & & & 0.631 & 0.931 \\
\hline MS1. Product (services) strategy & 3.939 & 0.877 & 0.015 & 58.737 & & \\
\hline MS2. Pricing strategy & 3.703 & 0.654 & 0.049 & 13.303 & & \\
\hline MS3. Place (location) strategy & 4.002 & 0.787 & 0.030 & 26.057 & & \\
\hline MS4. Promotion strategy & 3.924 & 0.827 & 0.027 & 30.125 & & \\
\hline MS5. Physical evidence strategy & 4.105 & 0.834 & 0.025 & 33.966 & & \\
\hline MS6. Proccess or service delivery strategy & 3.776 & 0.871 & 0.020 & 42.554 & & \\
\hline MS7. People or personnal strategy & 3.467 & 0.687 & 0.059 & 11.643 & & \\
\hline MS8. Patient safety strategy & 4.187 & 0.790 & 0.028 & 28.269 & & \\
\hline Hospital Performance (HP): & 3.873 & & & & 0.527 & 0.847 \\
\hline HP1. Bed Occupancy Rate (BOR) & 4.037 & 0.750 & 0.035 & 21.308 & & \\
\hline HP2. Cost recovery & 3.916 & 0.672 & 0.072 & 9.273 & & \\
\hline HP3. Market share & 3.827 & 0.835 & 0.027 & 30.648 & & \\
\hline HP4. Employee satisfaction & 3.723 & 0.657 & 0.047 & 13.904 & & \\
\hline HP5. Patients and their families satisfaction & 3.842 & 0.701 & 0.048 & 14.688 & & \\
\hline
\end{tabular}

Thus, can be drawn conclusion that this research was fir to be used to measure all research variables because it has high validity and reliability. This result can be proved through score of correlations of latent variables (SE) as showed in Table 3.

Tabel 3: Correlations of Latent Variables (SE)

\begin{tabular}{|l|c|c|c|}
\hline & $\begin{array}{c}\text { Market } \\
\text { Orientation }\end{array}$ & $\begin{array}{c}\text { Marketing } \\
\text { Strategy }\end{array}$ & $\begin{array}{c}\text { Hospital } \\
\text { Performance }\end{array}$ \\
\hline Market Orientation & 1 & & \\
\hline Marketing Strategy & 0.759 & 1 & \\
\hline Hospital Performance & 0.603 & 0.570 & 1 \\
\hline
\end{tabular}

* significant at .05 level

Based on the output of the PLS model, the structural model and hypothesis testing is done by looking at the value of the estimated path coefficients and t-values statistically significant at $\alpha=0.05$. Based on the conceptual framework, the hypothesis testing and the relationship model between variables can be done in testing the direct effect path coefficients. The test results obtained predictive valuerelevance of Q2 $=0.7426$ or $74.26 \%$. That is the accuracy or 


\section{International Journal of Science and Research (IJSR) \\ ISSN (Online): 2319-7064}

Index Copernicus Value (2013): 6.14 | Impact Factor (2015): 6.391

precision of the model of this study can explain the diversity of variables influence market orientation and marketing strategy on hospital performance of $74.26 \%$. The remaining $25.40 \%$ is explained by other variables that are not included in this research model. Because it is said to be good models or the model is said to have a good estimate of value. In the end, the model can be used for hypothesis testing. That is, the value of Q2 obtained from the model is said to have an accuracy or precision of a good model because the value is above $60 \%$. Next, the structural model was evaluated by looking at the path coefficient analysis between latent variables. The result of the test is presented in path diagram in Figure 1 and Table 4. Next, structural model was evaluated by looking at the score of path coefficient relation among the latten variables.

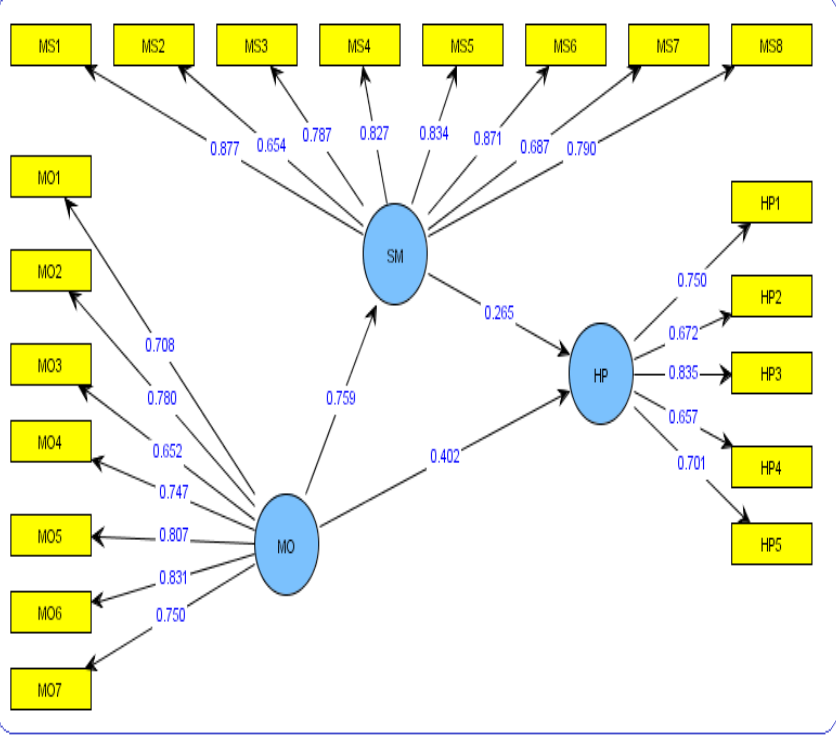

Figure 1: Hypothesis Testing and Path Coefficient

Table 4: Structural Model PLS for Bootstrapping results

\begin{tabular}{|c|c|c|c|c|c|}
\hline \multirow{2}{*}{$\begin{array}{l}\text { Hypothesis } \\
\text { Testing }\end{array}$} & \multicolumn{4}{|c|}{ Path Coefficients } & \multirow{2}{*}{ Empirical Evidence } \\
\hline & Estimate & SD & t- Statistic & p-value & \\
\hline $\mathrm{H}_{1} \mathrm{MO} \rightarrow \mathrm{SM}$ & 0.759 & 0.035 & 21.896 & 0.0000 & Significant Accepted \\
\hline $\mathrm{H}_{2} \quad \mathrm{MO} \rightarrow \mathrm{HP}$ & 0.402 & 0.088 & 4.573 & 0.0000 & Significant Acce \\
\hline $\mathrm{H}_{3} \mathrm{SM}->\mathrm{HP}$ & 0.265 & 0.087 & 3.057 & 0.0026 & cant $\mathrm{Acc}$ \\
\hline \multicolumn{6}{|c|}{ Pengaruh Variabel Mediasi } \\
\hline Eksogen & ediasi & Endogen & \multicolumn{2}{|c|}{ Coefficients } & Results \\
\hline $\mathrm{H}_{3 \mathrm{a}} \mathrm{MO}->$ & SM-> & HP & \multicolumn{2}{|c|}{0.201} & $\begin{array}{l}\text { Partial } \\
\text { Mediation }\end{array}$ \\
\hline
\end{tabular}

Notes: Market Orientation; MS = Marketing Strategy; HP = Hospital Performance $\mathrm{SD}=$ Standard deviation and $\mathrm{p}$-value $=$ significant at .05 level

Result of hypothesis testing in Figure 1 and Table 4 show the effect of market orientation towards marketing strategy was proved by estimate score of path coefficient $=0.759$ with tstatistic $=21.896$ and p-value $=0.000<\alpha=0.05$. Result of hypothesis testing $\left(\mathrm{H}_{1}\right.$, Accepted) proved that market orientation has positive and significant effect towards marketing strategy. Estimate score of path coefficient of market orientation towards hospital performance $=0.402$ with t-statistic $=4.573$ and p-value $=0.000<\alpha=0.05$. Result of hypothesis testing $\left(\mathrm{H}_{2}\right.$, Accepted) proved that market orientation has positive and significant effect towards hospital performance. Result of hypothesis testing of marketing strategy towards hospital performance obtained that the estimate score of path coefficient $=0.265$ with statistic $=3.057$ and $p$-value $=0.003<\alpha=0.05$. This result proved $\left(\mathrm{H}_{3}\right.$, Accepted) that marketing strategy has positive and significant effect towards hospital performance. It means that the better the marketing strategy decision gives more significant contribution towards hospital performance.

Finally testing the effect of mediation aimed at detecting the position of Intervening variables in the model. Mediation testing was conducted to determine the nature of the relationship between both variables as variable complete mediation, partial mediation and not partial mediating variables. PLS approach mediating variable testing can be done through difference coefficients. Approach coefficient differences using methods of inspection to perform analysis without involving the mediating variables. The evaluation results of testing the effect of market orientation on hospital performance at an early model with variables mediating role involves marketing strategy, show market orientation directly significantly influence the marketing strategy and hospital performance. Then the variable marketing strategy is also a significant effect on hospital performance, so that the nature of the mediating effect of market orientation on hospital performance through the role of marketing strategy is a partial mediation. There is enough evidence to accept (H4) that high marketing strategy can act as a mediating influence between market orientation and hospital performance. That is market orientation can directly affect the hospital performance can also be through the role of marketing strategy.

\section{Discussion}

Market orientation is very important to be implemented in managing the hospital industry. It is useful to get information about market and competitors, spread the information to the whole hospital activities. Findings in this research show that market orientation has positive and significant effect towards marketing strategy and hospital performance. It proves that good implementation of market orientation is able to support variety of changes in increasing marketing strategy and hospital performance. The empiric evidence from respondents' assessment and market orientation measurement are more reflected through the indicator of referral system orientation, while indicator of marketing strategy by product (services) strategy and hospital performance is market share. Finding of the research that good market orientation can increase marketing strategy and hospital performance proves the theory as stated by Kotler et.al., 2008, Cravens \& Piercy (2003), Lings Ian \& Gordon E.Greenley, (2009); Ferrel \& Hartline (2011); Narver \& Slater, 1990; Esteban, et.al., 2001; Gopalakrishna and Ram Subramanian, 2004; and Ashikia Olalekan, 2011. Next, it supports research finding by Narver \& Stanley F. Slater (1990); Kamalia La Ode \& J. Suprihanto (1998); Raju P.S., et.al (2000); Lonial S.C. \& P.S. Raju (2001); Esteban A.et.al., (2001); Bhalerao S and Rajendra Singh (2012); dan Kamalia La Ode (2013) that market orientation has positive and significant effect towards marketing strategy and hospital performance. 


\section{International Journal of Science and Research (IJSR) \\ ISSN (Online): 2319-7064}

Index Copernicus Value (2013): 6.14 | Impact Factor (2015): 6.391

The findings of this study show positive influence marketing strategy and significant hospital performance. It means that marketing strategy in product (services) strategy is able to support the change in increasing hospital performance. This research finding can prove the theory of Kotler et al, (2008) stated that the marketing strategy is an important role in improving the health care system, related to the provision of values for the target market in the future. While the marketing mix is defined by Pour B.S., et.al. (2012) is a set of variables that can be controlled in which companies can use to affect the response of buyers. Marketing strategy known as the marketing mix (7Ps) includes: product (service), price, place (distribution, accessibility, and location), promotion strategy, physical evidence, process and people (Sreenivas, et al., 2013, and Ahmad, et al, 2013) and performance (Johnson \& Johnson, 1996), namely patient safety. This research finding support finding by Pour B.S., et al, (2012) concluded that there is a significant relationship between the diversity of service marketing mix with an increase (attract) customers. Dolatabadi et al. (2013) concluded, packaging, price, place, advertising, promotion and quality affect the performance.

The evaluation results of testing the effect of market orientation on hospital performance at an early model with variables mediating role involves marketing strategy, show market orientation directly significantly influence the marketing strategy and hospital performance. Then the variable marketing strategy is also a significant effect on hospital performance, so that the nature of the mediating effect of market orientation on hospital performance through the role of marketing strategy is a partial mediation. That is market orientation can directly affect the hospital performance can also be through the role of marketing strategy. The findings of this study that marketing strategy can act as a perfect mediating variables influence the market orientation with hospital performance can prove contingency theory (Thompson, 1967). The best approach to improve the organization's performance can be explained either universally, contingency and configuration of elements of the independent (Donaldson, 2001). The results also support the structural contingency theory that the success of the organization conducts its activities depending on the strategy used (Galbraith, 1973: 98).

\section{Conclusion}

The result of this research shows that marker orientation have significant effect towards the increasing of marketing strategy and hospital performance. Next, Increased marketing strategy proved to be able to make a significant contribution to the hospital performance. The findings of this study reflect that high marketing strategy at the hospital industry in Southeast Sulawesi is able to support a variation changes in hospital performance improvement. The evaluation results of testing the effect of market orientation on hospital performance at an early model with variables mediating role involves marketing strategy, show market orientation directly significantly influence the marketing strategy and hospital performance. Then the variable marketing strategy is also a significant effect on hospital performance, so that the nature of the mediating effect of market orientation on hospital performance through the role of marketing strategy is a partial mediation. That is market orientation can directly affect the hospital performance can also be through the role of marketing strategy.

\section{References}

[1] Acikdilli Gaye, Dr., 2013. The Effect of Marketing Capabilities and Export Market Orientation on Export Performance, Interdiciplinary Journal of Contemporary Research In Business, Vol. 5 No. 6. Ijcrb.webs.com.

[2] Ahmad Ala'Eddin Mohammad Khalaf, Abdullah Ali AlQarni, Omar Zayyan Alsharqi, Dalia Abdullah Qolai \& Najla Kadi, 2013. The Impact of Marketing Mix Strategy on Hospital Performance Measured By Patient Satisfaction: An Empirical Investigation on Jeddah Private Sector Hospital Senior Managers Perspective, International Journal of Marketing Studies, Vol.5, No. 6; 2013 ISSN 1918-719X E-ISSN 1918-7203 Published By Canadian Center of Science and Education;

[3] Ahmed R.R., \& Ahmed Saeed, 2012. Ethical and Non Ethical Pharmaceutical Marketing Pratices : Case Study of Karachi City, Interdisciplinary Journal Of Contemporary Research In Business, Vol. 3, No. 11.

[4] Akinyele Samuel Taiwo, 2010. Strategic Marketing Strategies on Performance of Firms in Nigerian Oil and Gas Industry, Journal of Emerging Trends in Economics and Management Science (JETEMS) 1 (1) 23 - 36, Nigeria;

[5] Asikhia, Olalekan, 2011. Adjusted Narver and Slater's Market Orientation Concept and Firm Performance in Nigerian Companies, Global Journal Of Management And Business Research, Volume 11 Issue 7 Version, Publisher, Global Journal Inc. (USA);

[6] Bennet Silalahi, 1989. Principles of Hospital Management, Principles of Hospital Management, Management Development Institute of Indonesia, Jakarta.

[7] Beracs Jozsef \& Gabor Nagy, 2010. Effect of Business Environment on Market Orientation and Performance in An Emerging Country, Vol. XXII (2010) pp. 243-254;

[8] Buckley Patrick T, 2009. The Complete Guide To Hospital Marketing, Second Edition Pro Inc. in US.

[9] Cooper, D. R., dan Schindler, P. S., 2003. Business Research Methods. Eight Edition. McGraw-Hill/Irwin, New York, NY 10020.

[10] Cravens, David W. \& Nigel F Piercy. (2003). Strategic Marketing, Seventh Edition, cGraw-Hill, New York

[11] Department of Health. R.I., 2004. Guidelines for Accreditation of Hospitals In Indonesia, the Ministry of Health R.I., Yanmed Director General, Commission on Accreditation of Hospitals and other Sarkes, Jakarta.

[12] Department of Health. R.I., 2008. Minimum Service Standards for Hospitals, Directorate General of Medical Services Ministry of Health R.I., Jakarta.

[13] Dolatabadi HR, Mohammad Hossein Forghani, Sayed Mehdi Tabatabee \& Fatemeh Faghani, 2013. Effect of Appropriate Marketing Mix Strategies on Iranian Protein Products Export Performance, International Journal of Academic Research in Accounting. Finance 


\section{International Journal of Science and Research (IJSR) \\ ISSN (Online): 2319-7064}

Index Copernicus Value (2013): 6.14 | Impact Factor (2015): 6.391

and Management Science, Vol. 3 No. 3, July 2013, pp.21-27, ISSN 225-8329, HRMARS;

[14] Donaldson, L., 2001. The Contingency Theory of Organizations. Sage, Thousand Oaks, CA.

[15] Esteban Agueda, Angel Millan, Arturo Molina and David Martin Consuegra, 2001. Market Orientation in Sevice A Review an Analysis, Europan Journal Of Marketing, Vol.36 No. 9/10, 2002, pp. 1003-1021.

[16] Ferrell O.C. \& Michael D. Hartline, 2011. Marketing Strategy, Fifth Edition, Printed in The United States of America.

[17] Galbraith, J.R., 1973. Designing Complex Organizations. Addison-Wesley.

[18] Gopalakrishna P \& Ram Subramanian, 2014 : Emphasis or Balance?, The Impact of Form of Market Orientation on Performance, Journal of Global Marketing, Vol. 17(2/3)

[19] Hair JR Joseph F., William C. Black, Berry J. Babi Ralph, \& E. Anderson, 2010. Multivariate Data Analysis, Seventh Edition, By Pearson Prentice Hall;

[20] Heiens Richard A. \& Larry P. Pleshko, 2011. A Contengency Theory Approach To Market Orientation dan Related Marketing Strategy Concepts : Does Fit Relate to Profit Performance? Management \& Marketing Challenges for the Knowledge Society, 2011, Volume 6 No. 1 pp.19-34;

[21] Idar Riduwan, Yuslina Yusof \& Rusli Mahmood, 2012. The Effect of Market Orientation as Predictor To Strategic Planning Practices and Performance Relationship : Evidence From Malysian SMESs, Published by Elsevier

[22] Jaworski Bernard J. \& Ajay K. Kohli, 1996. Market Orientation: Review, Refinement, and Roadmap, Journal Of Market Focused Management, Klawer Academic Publishers, Boston, Manufactured in Netherlands;

[23] Johnson \& Johnson, 1996. Marketing The Hospital, Papers Presented At the Seminar, FK-UGM, September 21, 1996 in Yogyakarta.

[24] Kamalia La Ode, 2013, Influence Marketing and Strategy Marketing Orientation Toward Improved Performance Bau-bau City General Hospital, Mandala Foundation Waluya Kendari (not yet published).

[25] Kamalia, La Ode \& J. Suprihanto, 1998. Factors Affecting Public Interest For Medication Into Hospital Buton In Marketing Strategy Development Efforts, Manuscript Publication MMR-IKM-FK-UGM, Yogyakarta;

[26] Lings Ian, 2002. Internal Market Orientation, Market Orientation and Financial Performance : Some Empirical Evidence, Aston University UK, ANZMAC 2002 Conference Proceedings;

[27] Lonial Subhash C. \& P.S. Raju, 2001. The Impact of Environmental Uncertainty on The Market Orientation - Performace Relationshi: A Study of The Hospital Industry, Journal of Economic and Social Research, 3(1) 2001, 5-27.

[28] Malhorta, Naresh 2010. Marketing Research, An Applid Orientantion. The Prentice-Hall. Inc., New Jersey.

[29] Mutongoreni N. Ariel \& Nelson Jogero, 2014. Market Orientation in Public Health Sector of Mutare Zimbabwe, International Journal of Academic Researh in Business and Social Science, Vol.4, No. 2, ISSN 2222-6990;

[30] Mwangi E.W. \& Kepha, 2013. Effects of Competitive Strategies on the Performance of Mission Hospitals in Kenya (A Case of Kijabe Mission Hospital), International Journal of Science and Research (IJSR), ISSN (Online: 2319-7064, Volume 2 Issu 11, November 2013.

[31] Narver John C. \& Stanley F. Slater, 1990. The Effect of Market Orientation on Business Profitability, Journal of Marketing, October, pp.20-35;

[32] Raju, P.S. Subbash C. Lonial, Yash P. Gupta and Craig Ziegler, 2000. „The Relationship Between Market Orientation and Performance in The Hospital Industry, A Structural Equations Modeling Approach;

[33] Schalk Adrianus Philip, 2008. Effect of Market Orientation on Business Performance : Empirical Evidence From Iceland, Marketing and International Business;

[34] Scott Backer JD.CPA, Amber McGraw Walsh, JD, and Anna Timmerman, JD McGuire Woods, November 06, 2012. Key Issues For Hospital and Healthcare Systems.

[35] Sekaran Uma, 2003. Research Methods For Business, By John Wiley \& Sons Inc.USA;

[36] Sheaff Rod, 2002. Responsive Healthcare, Marketing For A Public Service, Open University Press, Buckingham - Philadelphia, USA;

[37] Sin Leo YM, et.al, 2004 dan 2013. Analysis of The Relationship Between Market Orientation and Business Performance in The Hotel Industry, Departement of Marketing, The Chines University of Hongkong;

[38] Solimun, 2012. Pemodelan Generalized Structured Component Analysis (GeSCA). Statistics Studies Program Faculty, PDIM FEB Universitas Brawijaya

[39] Sreenivas, B. Srinivasarao, and U. Srinivasa Rao, 2013. An Analysis on Marketing Mix in Hospital, International Journal of Advanced Research in Management and Social Science (IJARMSS), Vol. 2, No.4.

[40] Susana Meyer Goldstein, Peter T. Ward, G. Keong Leong, and Timothy W. Butler, 2002. The Effect of Location, Strategy, and Operations Technology on Hospital Performance, Journal of Operation Management,

[41] Thompson, J.D., 1967. Organizations in Action. McGraw-Hill, New York, NY. 